\title{
Economic modelling of the management of dredged marine sediments
}

\author{
Joseph R. Harrington ${ }^{1}$, Jimmy Murphy ${ }^{2}$, Mary Coleman², Declan Jordan ${ }^{3}$, \\ Tristan Debuigne ${ }^{4}$, Gabor Szacsuri ${ }^{1}$ \\ ${ }^{1}$ School of Building \& Civil Engineering, Cork Institute of Technology; Ireland; \\ email: joe.harrington@cit.ie (corresponding author) \\ ${ }^{2}$ Beaufort, Environmental Research Institute, University College Cork, Ireland \\ ${ }^{3}$ School of Economics, University College Cork; Ireland \\ ${ }^{4}$ Cd2e-Création Développement Eco-Entreprises; France
}

(C) 2016 Authors. This is an open access publication, which can be used, distributed and reproduced in any medium according to the Creative Commons CC-BY 4.0 License requiring that the original work has been properly cited.

Received: 22 October 2015; accepted: 31 August 2016

\begin{abstract}
This paper presents and applies an economic model developed for the management of dredged marine sediments. The model predicts direct project costs and direct, indirect and induced economic impacts. The model is applied to analyse the economic aspect of the specific potential beneficial use of dredged sediment for land reclamation in an Irish context. The model results show the potential economic benefits to land reclamation of using dredged sediment including its value as a potential substitute for quarry based material and as an alternative to traditional offshore dredged sediment disposal, where appropriate. Analysis of other sediment management approaches including wetland creation, is also presented with the results for wetland creation indicating its potential, where appropriate, as a valuable alternative to offshore disposal. Indicative economic benefits are predicted by the model for the different dredge sediment management approaches analysed.
\end{abstract}

Keywords: dredging, sediments, sediment management, economic modelling, economic impacts, economic analysis, beneficial use

\section{INTRODUCTION}

This paper presents an economic model developed to analyse the management of dredged sediments. This provides a potential management tool to support the sustainable use of dredged marine sediments which continues to be a major challenge for many ports and harbours worldwide. It also contributes to enhancing the knowledge base of dredged sediment management in an economic context.

Dredging involves the removal of sediments from the aquatic environment, including port and harbour navigation channels, berthing areas, and marinas. This activity is essential to providing navigable access to waterways and maintaining this essential infrastructural component and by extension critical to international trade and development in an interconnected world.

The quantities of dredge sediment generated internationally are significant and in a European context involve countries such as The Netherlands, Germany, France and the United Kingdom each managing between $30-50$ million $\mathrm{m}^{3}$ of sediments on an annual basis (Bortone \& Palumbo 2007). The annual dredge volume for the United States is estimated to range from 200 to 250 million $\mathrm{m}^{3}$ (Eisma 2006). Ireland, by comparison, has a significantly lower dredge quantity to manage at approximately 1.2 million $\mathrm{m}^{3} /$ year (Sheehan 2012). 
Sustainable dredged sediment management is a key feature of dredging projects; a wide range of management options may initially be considered and may involve disposal, treatment and/or beneficial use. Disposal options include onshore disposal or offshore disposal to a confined or open water facility. A wide range of treatments are available and depend on the sediment characteristics and the end use identified. Beneficial use options are many and varied and may be broadly categorised under engineering uses where the dredged sediment is often a substitute for traditional land based sources, environmental enhancement on land or in an aquatic environment and agricultural and/or product uses where useful and potentially marketable products are developed.

Greater detail and guidance on the potential dredged sediment management practice may be sourced from the literature including United States Army Corps of Engineers (1987, 2007, 2012, 2014), PIANC (1992, 2009a, b, c), OSPAR Commission (2009) and the Environment Agency (2010). Recent research work in a European context includes the SMOCS Project (2012), the DredgDikes Project - Dredge Material in Dike Construction (2013), the TIDE - Tidal River Development Project (2013), the PRISMA Project (2014), the CEAMaS Project (2015), the USAR Project (2016) and from the Central Dredging Association (2015).

Ireland, although its dredge sediment volumes are relatively low, faces a range of challenges similar to countries that generate larger dredging volumes. These management challenges include seeking feasible alternatives to disposal at sea for clean, uncontaminated sediment (particularly for the finer grained fraction) and addressing the requirements of managing contaminated sediments for capital projects. Primary responsibility for dredge sediment management in Ireland lies with the main commercial ports who have an on-going maintenance dredge requirement. Dredged sediment management issues, practice and trends in Ireland have previously been presented by, for example, Harrington et al. (2004), Sheehan \& Harrington (2012) and Harrington \& Smith (2013).

A wide range of factors may influence the most appropriate sediment management technique required including the characteristics of the sediment, whether it is contaminated or not, the dredge volume involved, the local site conditions including site accessibility, and current local, national and international practice. These feasibility issues are generally dependent on a range of often inter-related technical, economic, environmental, legislative and societal factors. This paper focuses primarily on the economic aspects of dredge sediment management.

The economic model presented in this paper facilitates the analysis of both the direct project costs and the potential economic impacts of beneficial use projects. The model is applied to analyse a number of approaches to sediment management for Ireland for clean sediment; specifically land reclamation and wetland habitat creation (or enhancement) with comparison to the widely implemented practice of unconfined disposal to open water licensed offshore disposal sites. The model assesses the potential economic impact, accounting for costs and benefits, within the same time period. This means that longer-term economic benefits derived from beneficial use projects such as land reclamation and wetland creation, for example, are not included in the analysis. Such an analysis would require significant assumptions to be made on, among other things, the uses to which reclaimed land may be put, the suitability of wetlands to particular amenities, and even the rate at which future income would be discounted to the present value. Such an analysis would be very sensitive to the assumptions made, and therefore may not be reliable and robust. This means that the analysis conducted is in this paper is prudent, and is likely to underestimate the full longer-term economic benefits of alternatives to offshore disposal.

\section{METHODS}

\section{The general model framework}

The approach presented in this paper is based on the use of multipliers derived from input-output analysis of economic activity, where the output of one industry corresponds to the input of another industry (Leontief 1951). This facilitates the identification of the impact of activities within a business or a sector across the regional or national economy. These input-output models generate a multiplier index that measures the total effect of an 
increase in investment on employment or income. There are three types of multiplier effect: direct, indirect and induced. Direct effects refer to the impact on economic activity of the industry/development. Indirect effects refer to the impact arising from upstream or inter-sectoral linkages, such as the income or jobs accruing to suppliers. Induced effects are impacts arising from general household spending of those directly and indirectly employed by the industry/development. This approach is well established to model and estimate the economic impacts of industries and developments, for example Hawdon \& Pearson (1995), Weidmann (2009) and Ivanova \& Rolfe (2011).

Figure 1 presents the general economic modelling framework developed and the overall approach applied for dredged marine sediments. It involves identification of the National Economic Impact Area (e.g. a country), identification of the dredging site and its sediment characteristics, preliminary selection of the potentially feasible sediment management options and development of the full logistical chain of project activity (from dredge sediment generation through to ultimate placement or disposal).

Figure 2 presents a more detailed view of the modelling approach applied including model inputs and outputs. Direct costs and economic impacts (direct, indirect and induced) form the model output. Economic impacts are presented as contribution to Gross Domestic Product (GDP) and employment created.

\section{Direct costs}

The direct costs are the actual costs associated with completion of the project. The total direct cost of a project is the sum of all the individual process unit costs by the associated quantity involved. The individual process costs include for design and oversight, permitting and fee costs, sampling and analysis, dredger mobilization, dredging, transport of the dredged sediment, sediment management (including treatment as necessary) and associated construction works. Direct costs are included in the economic model for a number of countries (National Economic Impact Areas) including Ireland.

Some direct costs may be considered to be offset, depending on the project, by, for example, the value created from the sediment reuse (e.g. the potential value from land or a wetland created). Table 1 presents unit direct cost information gathered for Ireland which is used as input to the modelling analysis presented in this paper.

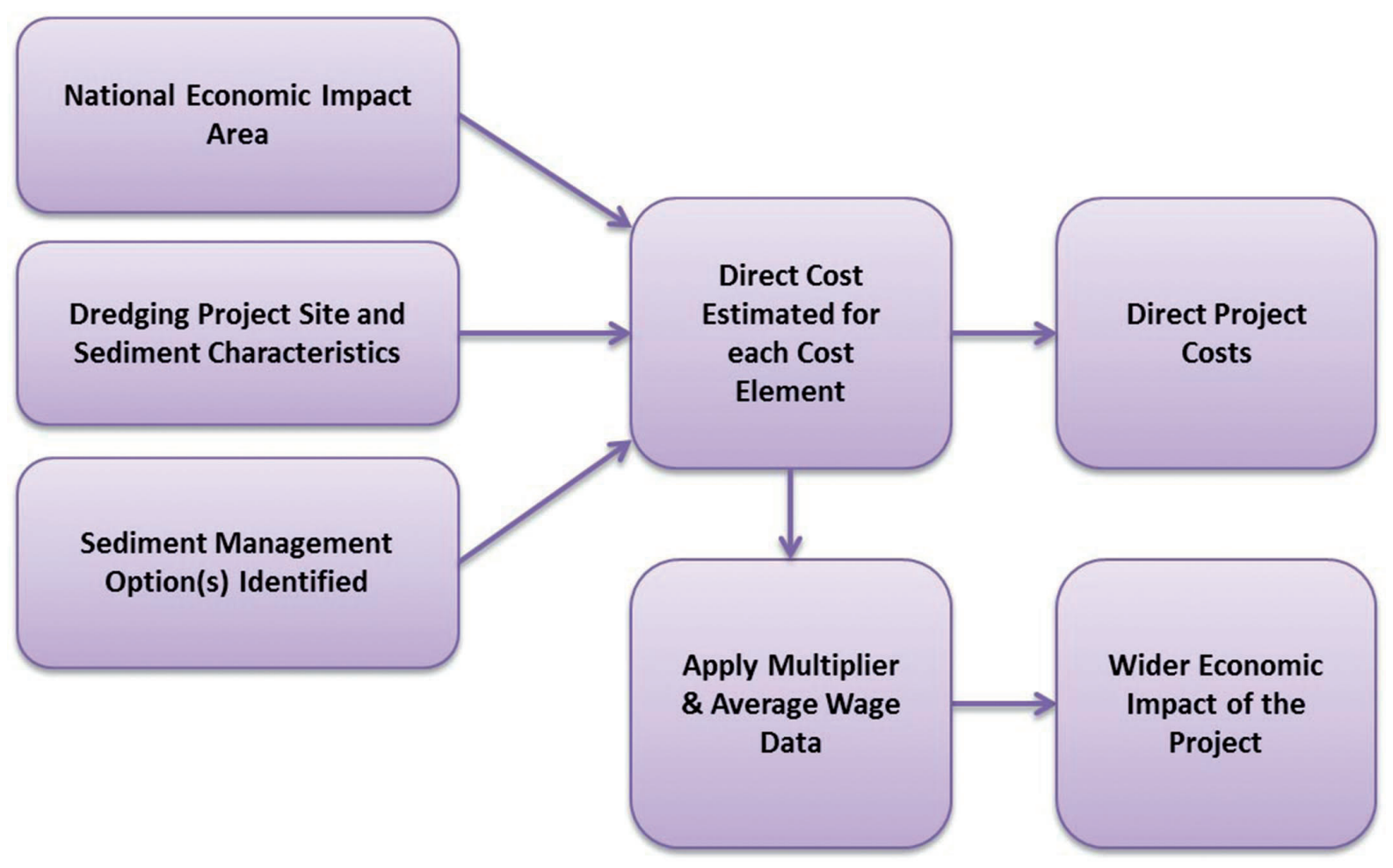

Fig. 1. Economic Modelling Framework 


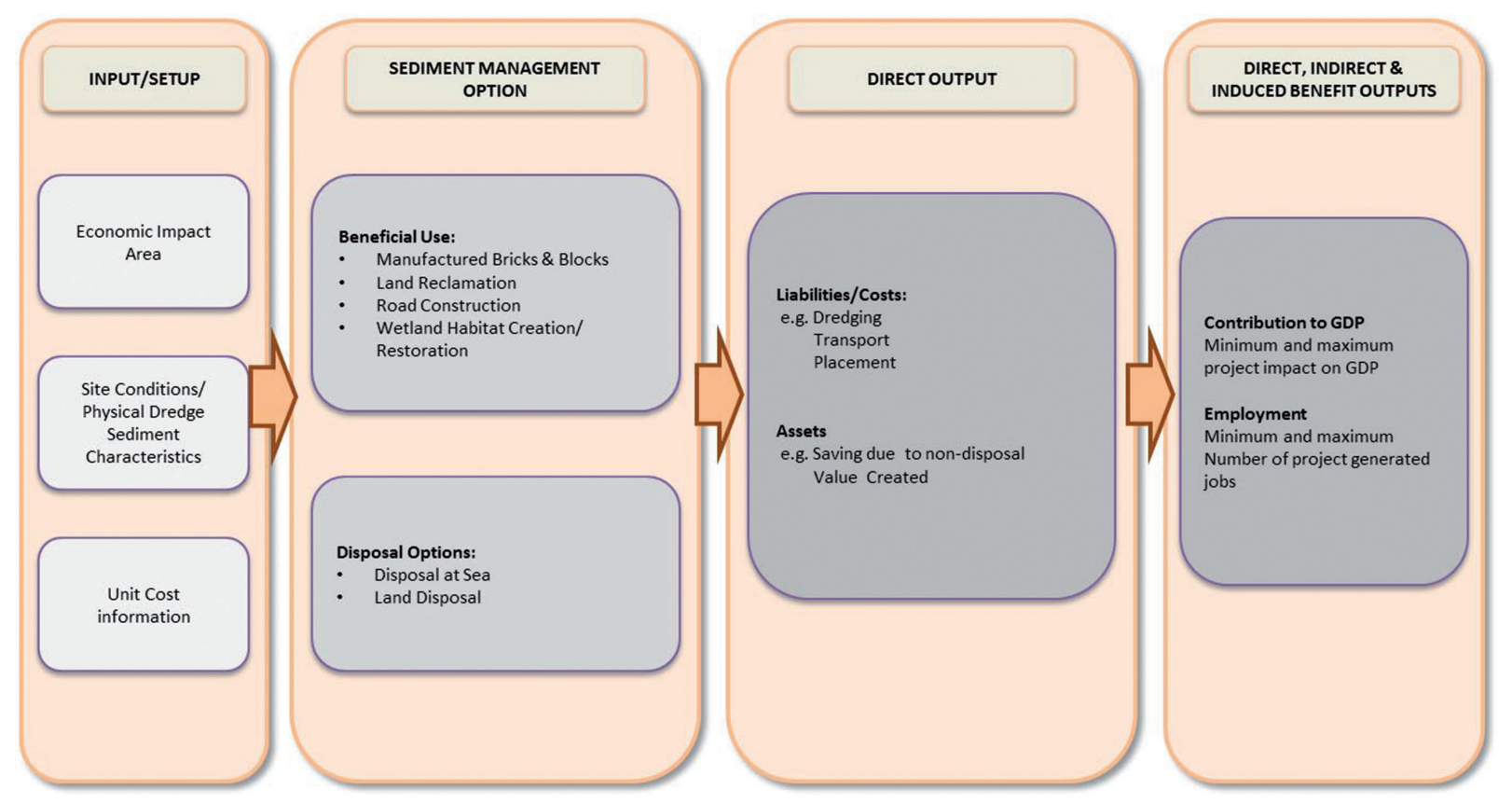

Fig. 2. The implemented model structure

Tab. 1. Direct cost data for specific sediment management processes for Ireland

\begin{tabular}{|l|l|c|}
\hline \multicolumn{2}{|c|}{ Management process steps } & Price \\
\hline \multirow{2}{*}{ Disposal costs on land [€/TMS] } & upland waste storage & $1^{1}$ \\
\cline { 2 - 3 } & environmental tax & $75^{2}$ \\
\hline Disposal at sea $\left[€ / \mathrm{m}^{3}\right]$ & $0.17^{1}$ \\
\hline Disposal at sea charges $[€]-$ volume dependent & $2000-18000^{3}$ \\
\hline Licencing fees and charges $[€]^{4}$ & $30000^{1}$ \\
\hline Water transport cost $\left[€ / \mathrm{m}^{3} / \mathrm{km}\right]$ & & $0.6-1.0^{1}$ \\
\hline \multirow{2}{*}{ Unloading costs $\left[€ / \mathrm{m}^{3}\right]$} & non-mechanical & $0.76^{1}$ \\
\cline { 2 - 3 } & mechanical & $4.0^{1}$ \\
\hline \multirow{2}{*}{ Land transport cost $[€ / \mathrm{t} / \mathrm{km}]$} & road - rural condition & $0.04^{1}$ \\
\cline { 2 - 3 } & road - urban conditions & $0.9^{1}$ \\
\hline Dredger mobilization $[€]$ & $70000^{1}$ \\
\hline Pipeline mobilization $[€]$ & $80-90^{1}$ \\
\hline Dredging cost $\left[€ / \mathrm{m}^{3}\right]$ & $3^{1}$ \\
\hline Pumping/rainbowing cost $\left[€ / \mathrm{m}^{3}\right]$ & & $1.30-1.50^{1}$ \\
\hline Environmental assessment $[€]$ & 15000 \\
\hline Monitoring $[€]$ & 35000 \\
\hline Sampling cost $[€ /$ sample] & 500 \\
\hline Analysis cost $[€ /$ sample] & 610 \\
\hline
\end{tabular}

${ }^{1}$ Sheehan (2012).

${ }^{2}$ Department of the Environment, Community and Local Government - Landfill levy.

${ }^{3}$ Irish Dumping at Sea (Fees) Regulations 2012.

${ }^{4}$ Including the Irish Environmental Protection Agency Disposal at Sea Licence Fee, the Foreshore Licence Fee and other Miscellaneous Permitting Costs. 


\section{Direct, indirect and induced economic impacts}

The approach to the estimation of the economic impacts, direct, indirect and induced, is presented below.

\section{Direct contribution}

GDP is an indicator of economic activity (typically over one fiscal year) which measures the total monetary value of the goods and services newly produced within a country (D'Alisa et al. 2015). In the economic model developed, the direct contribution to GDP of the project is estimated based on expenditure (i.e. how much money is invested in the construction/dredging sector for the specific project). The direct project contribution to GDP is equivalent to the total direct cost of the project.

The direct jobs generated include those associated with the project work, and, for example, any additional jobs in utilities and research and development. The number of direct jobs created is estimated based on equation:

$\mathrm{NDJ}=\mathrm{DCGDP} \cdot \mathrm{CE} / \mathrm{AAW}$

(for each sector identified with beneficial use)

where:

NDJ - Number of Direct Jobs, DCGDP - Direct Contribution to GDP [€],

$\mathrm{CE}$ - Compensation for Employees,

AAW - Annual Average Wage [€].

\section{Indirect contribution}

The indirect contribution to GDP is calculated by applying specific appropriate multipliers to the economic sectors with which there are inter-sector linkages with the project. Type I economic multipliers are used to estimate the financial results. The initial investment fees (or the direct cost of the individual elements of the project) are then deducted from this 'multiplied value' for each output/ project element and these values are summed to derive the indirect contribution to GDP. Indirect employment refers to the "supplier effect" of upstream and downstream suppliers (Blanco et al. 2009), including employment in other sub-sectors of the industry such as the manufacture of components for infrastructure and the provision of services (Kammen et al. 2010). The number of indirect jobs created (during the time period of the project) is estimated based on equation:

NIDJ = ICGDP $\cdot$ National Average CE/NAW

where:

NIDJ - Number of Indirect Jobs, ICGDP - Indirect Contribution to GDP [€], NAW - National Average Wage [€].

\section{Induced contribution}

The induced contribution to GDP is derived using the same approach as above for the indirect contribution to GDP, in this case using another multiplier, the adjusted Leontief Type II multiplier data, to calculate the induced economic impact.

Induced employment effects are the jobs created by the expenditure induced effects within the general economy due to the increased economic activity associated with the project and consumption spending of direct and indirect employees, including non-industry jobs. The induced contribution for each output is summed and this value is added to the minimum output to provide a minimum estimate of the jobs generated. The total (summed) is then added to the maximum output to provide a maximum estimate of the jobs generated based on equation:

NINJ $=$ INCGDP $\cdot$ National Average CE/NAW

where:

NINJ - Number of Induced Jobs, INCGDP - Induced Contribution to GDP [€].

The need to identify minimum and maximum levels of jobs created arises from different multipliers for sub-sectors and the inability to identify precisely the extent of the investment attributable to each sub-sector. The lower bound of the range reflects where all the investment is attributable to the sub-sector with the lowest multiplier, the upper bound reflects where all the investment is attributable to the sub-sector with the highest multiplier; the actual level of jobs must then lie within this range. 


\section{Economic modelling for sediment management in Ireland}

Sediment management practices that have been identified for analysis for Ireland are as follows and based on current national practice, needs and opportunities:

- Land Reclamation which has been practised for a range of primarily port expansion projects for the coarser sediment fraction,

- Wetland Creation/ Enhancement which has been limited in application but has significant potential,
- Disposal at Sea which is most widely applied particularly for the fine grained fraction.

Some comparison is also presented for road sub-base construction material which has not been undertaken in Ireland but has been implemented in France for road reconstruction at the Port of Dunkirk (Herman et. al. 2014). The detail available on this sediment management approach is not as extensive as for the other sediment management approaches analysed and thus will not be presented to the same level of detail for comparison purposes.

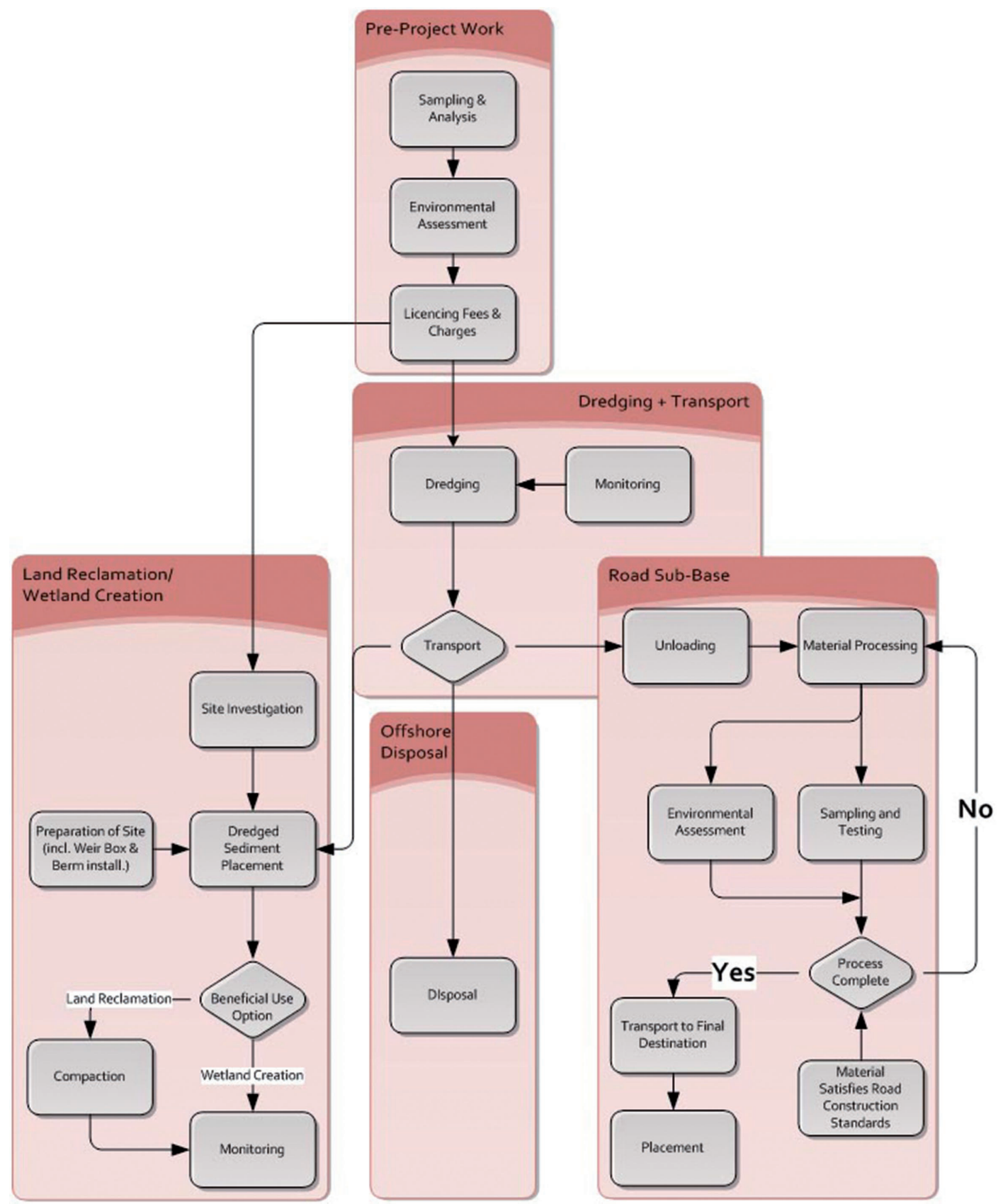

Fig. 3. Logistical supply chain for dredge sediment management 
Figure 3 presents the logistical supply chain included in the economic model for dredged sediment from generation to final placement for each management approach investigated (including for road sub-base construction for purposes of completeness). The model treats land reclamation and wetland creation in general as similar processes, however land reclamation includes the additional engineering compaction process (as outlined in Figure 3).

Model inputs include the direct unit costs and the sediment quantity for each process identified and the industry sub-sector specific economic multiplier and wage data. Type I economic multipliers for Ireland for the appropriate industry NACE subsector are applied for indirect economic impacts and the adjusted Leontief Type II multipliers based on available data for Scotland (relevant data is not available for Ireland) are applied for induced economic impacts. Whilst it is clear that sediment management projects have an induced impact on the national economy it is uncertain exactly what that impact will be and thus the Scottish data has been adjusted downward by reducing its effect by $50 \%$ to reflect that there is an induced impact whilst providing a more conservative approach for the Irish economy. All wage data applied is specific to Ireland (Central Statistics Office 2014). Model outputs include the direct cost of the individual elements or processes of the project and total costs, and the direct, indirect and induced contributions to GDP and employment created.

\section{RESULTS}

The economic model has been applied to a range of sediment management practices (as outlined above) with most emphasis on land reclamation and with comparison to wetland creation and offshore disposal.

The project scenario analysed involves a land reclamation project assuming a dredge volume of $100,000 \mathrm{~m}^{3}$ with a $2 \mathrm{~km}$ sail distance from the dredging site to the land reclamation site and with an average $2 \mathrm{~m}$ depth of fill assumed across the reclamation area. The sediment is assumed to be clean and uncontaminated.

Figure 4 presents the indicative direct costs including sampling, assessment and monitoring, design and oversight, dredging and transport and site preparation including a containment/ bund structure and placement, these total to approximately $€ 1.4 \mathrm{~m}$. It is assumed that any existing resources are not lost or displaced in this work, however such potential losses would need to be assessed on a site-specific basis. The potential asset created is the land value (DTZ Sherry FitzGerald 2014) with an estimated value of $€ 375,000$.

Figures 5 and 6 present the potential contribution to GDP and employment creation. The analysis indicates a maximum total contribution to GDP of nearly twice the value of the overall project (of overall $€ 2.7 \mathrm{~m}$ ). The estimated total number of jobs created is from approximately 22 to 27 jobs within the national economic impact area. As outlined above the full economic benefits are likely to be underestimated by the economic modelling work.

The effect of varying the dredge sediment volume and thus the area of land reclaimed (for an average depth of fill of $2 \mathrm{~m}$ ) was analysed and compared to the offshore disposal of sediment for a sail distance of $10 \mathrm{~km}$.

Figure 7 presents the direct project cost results for dredge volumes which show that, based on the assumptions made, land reclamation has a higher direct project cost than disposal at sea. However the modelling indicates that the land reclamation project becomes an economically viable option (for the parameter values modelled) if the sail distance to the offshore disposal site exceeds approximately $40 \mathrm{~km}$, a sail distance at the outer bound of current practice in Ireland but not excessive in an international context. Indeed longer sail distances are becoming a more common feature for dredge disposal projects in Ireland due to environmental considerations. As expected land reclamation provides a higher contribution to both GDP and employment created during the duration of the project; it is also likely to provide greater long term benefits.

A comparison between using dredged sediment and traditional quarry based material for the reclamation project scenario (for an average depth of fill of $2 \mathrm{~m}$ ) was also undertaken assuming the quarry to be a $10 \mathrm{~km}$ trucking distance from the project site. 


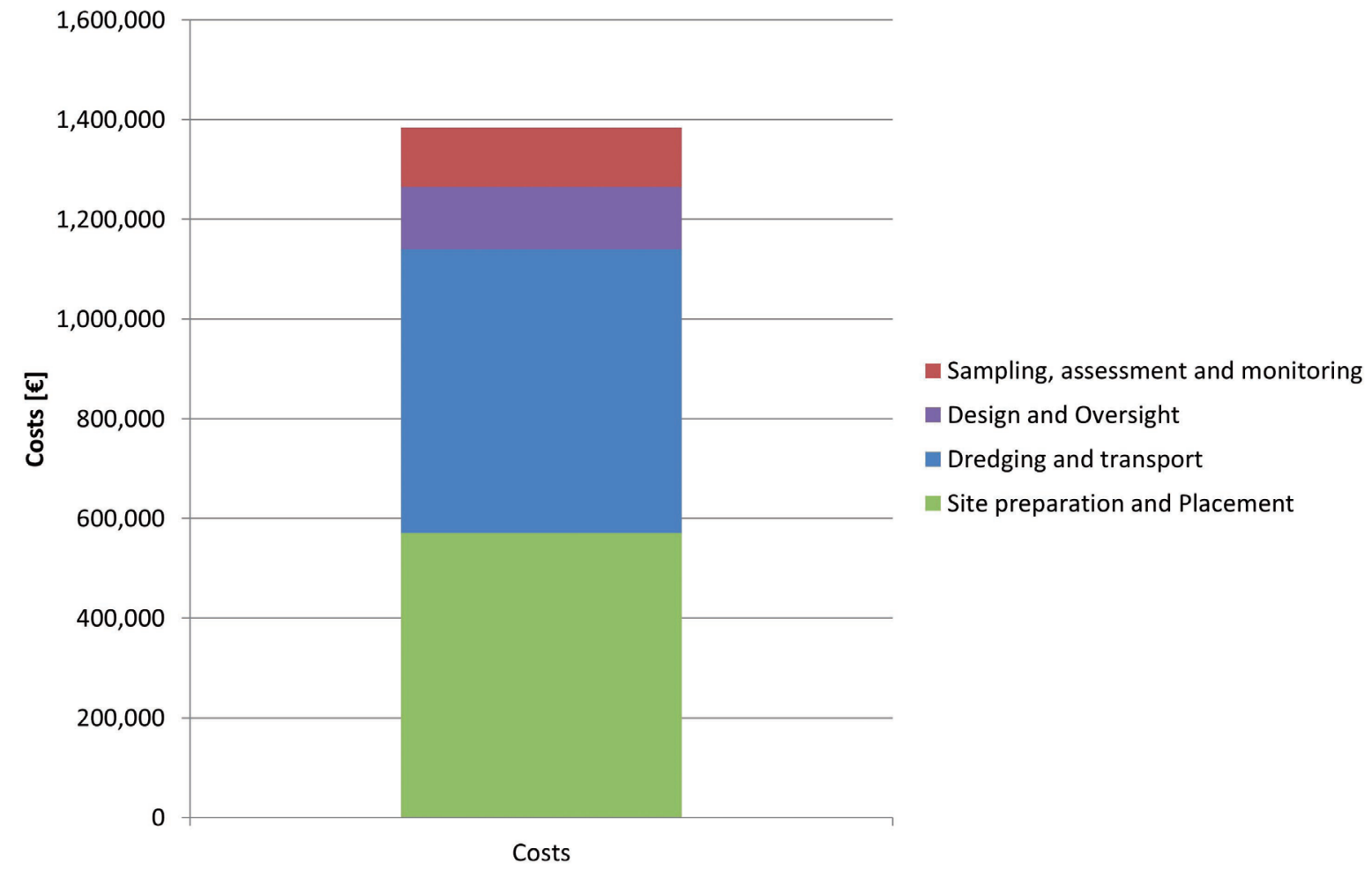

Fig. 4. Direct costs for the Land Reclamation Project

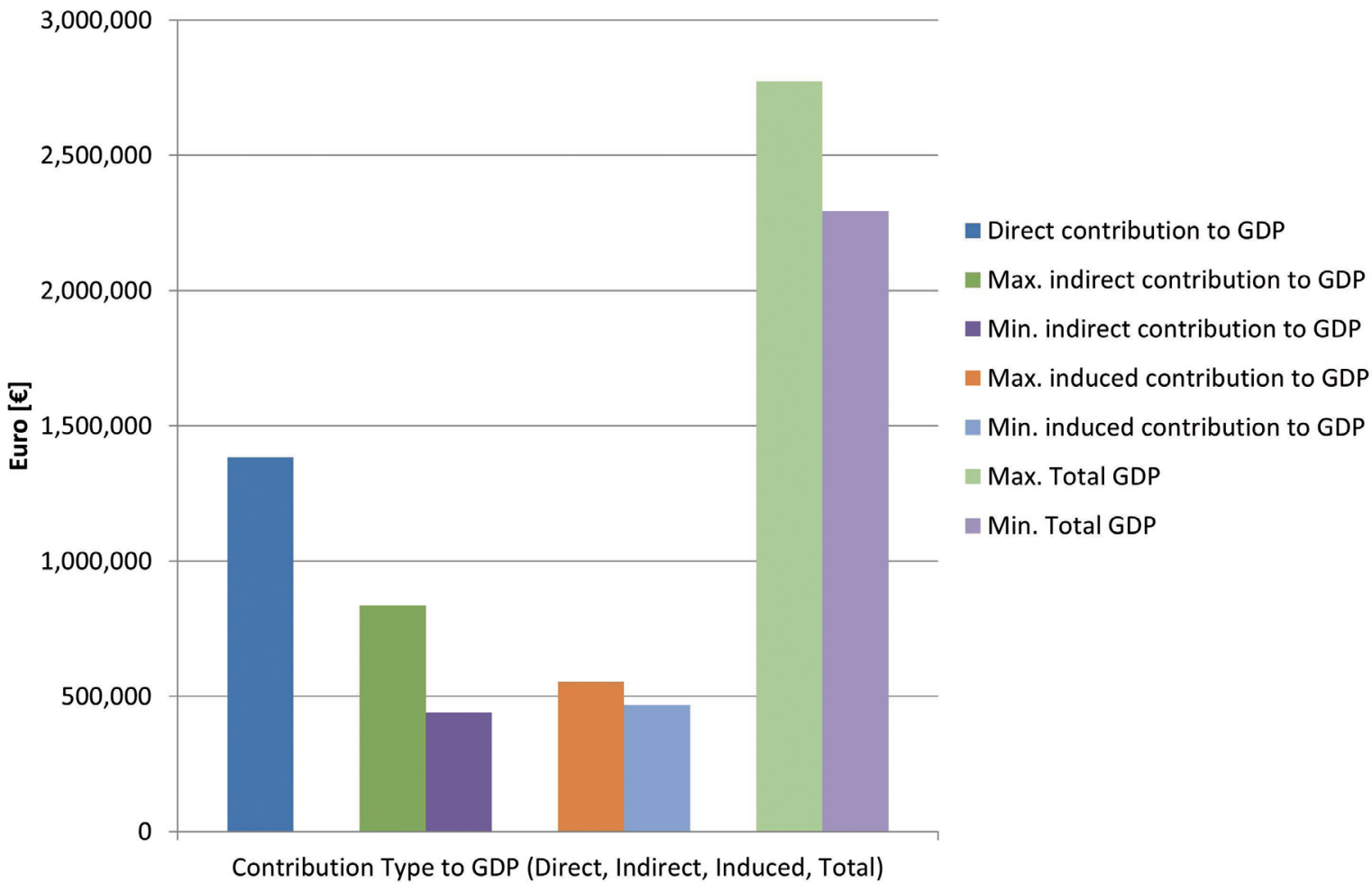

Fig. 5. Contribution to GDP for the Land Reclamation Project 


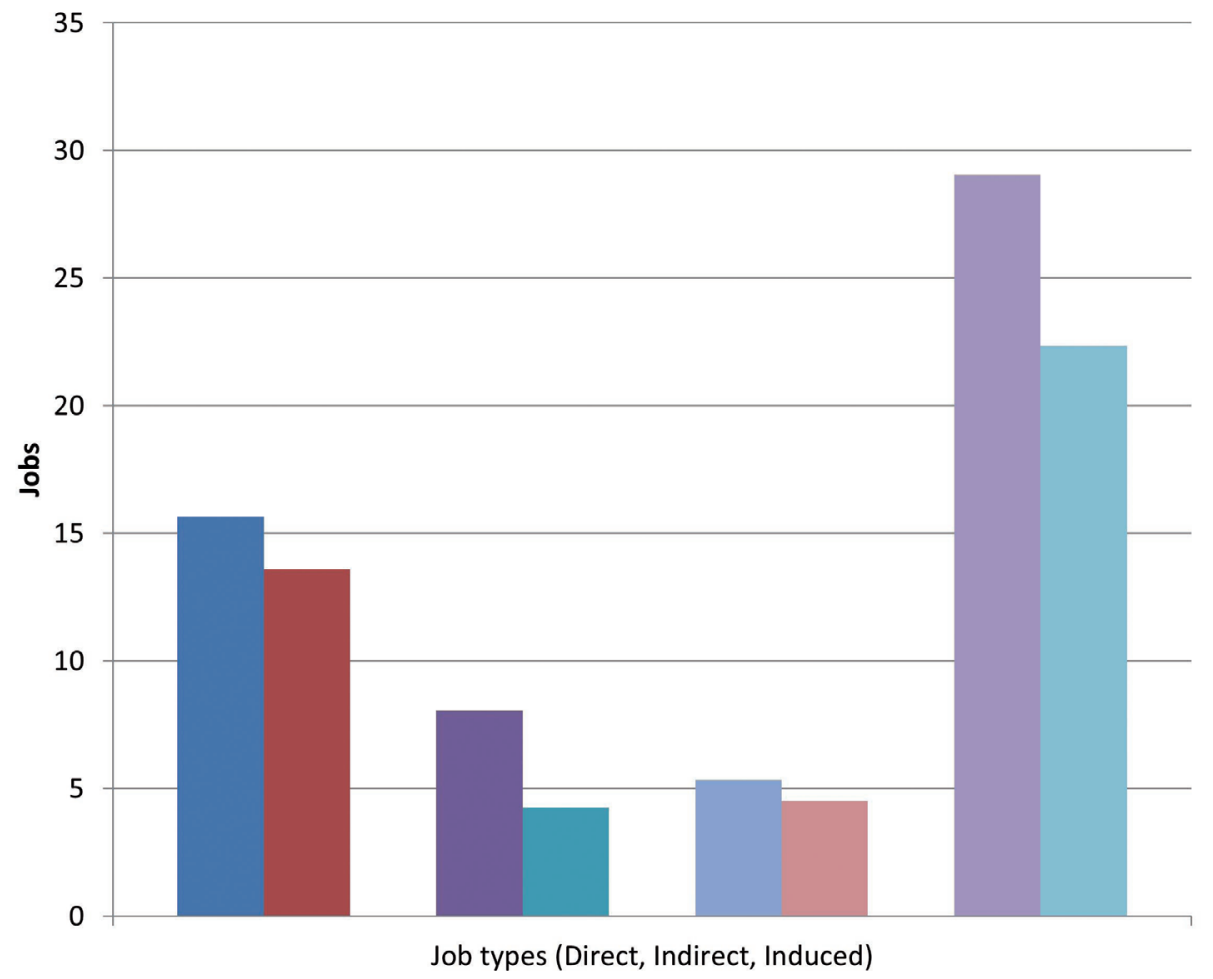

Max. direct jobs

- Min. direct jobs

- Max. indirect jobs

Min. indirect jobs

- Max. induced jobs

Min. induced jobs

Max. total jobs

Min. total jobs

Fig. 6. Contribution to Employment for the Land Reclamation Project

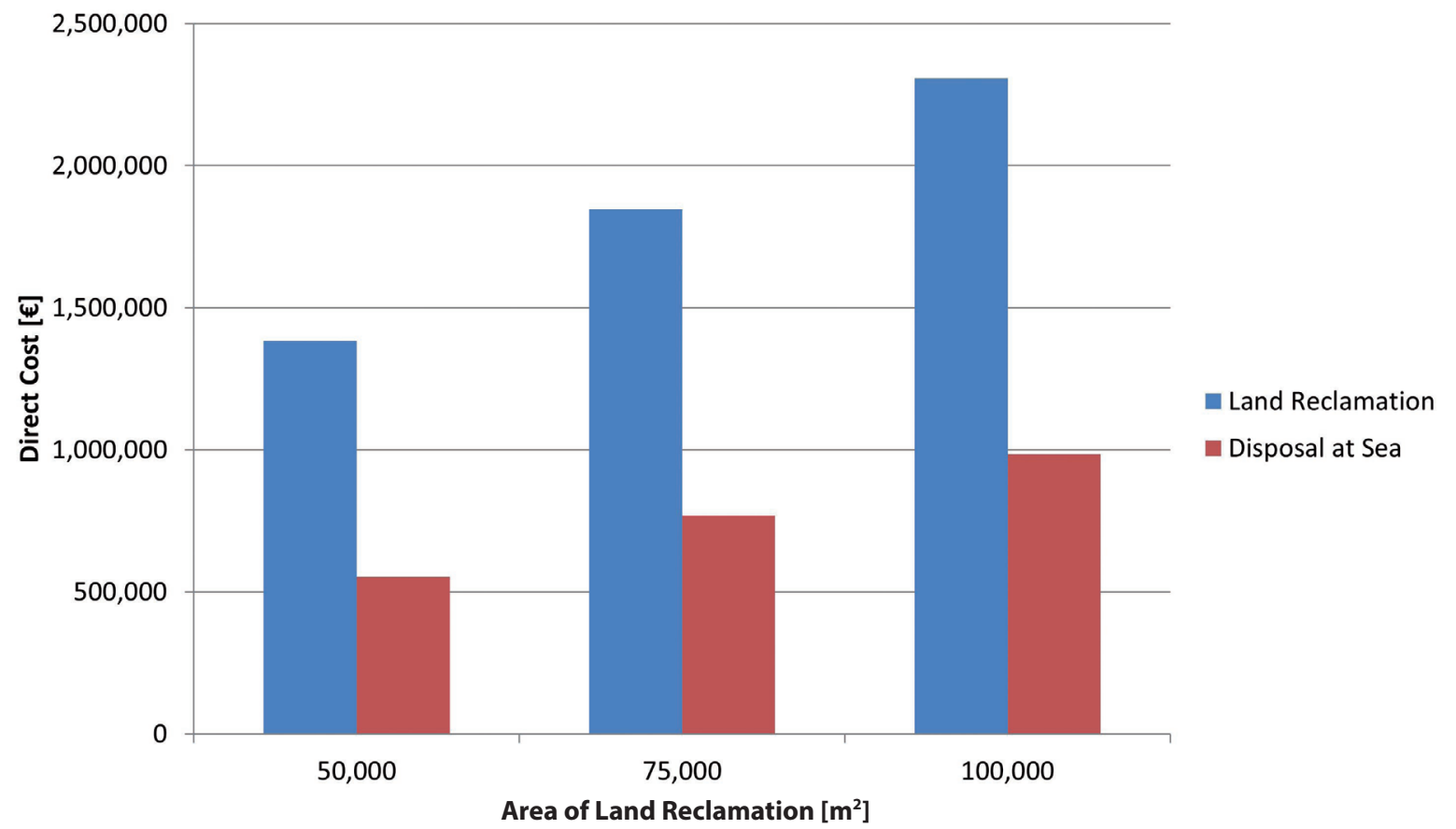

Fig. 7. Direct Economic Impact for Varying Land Area 


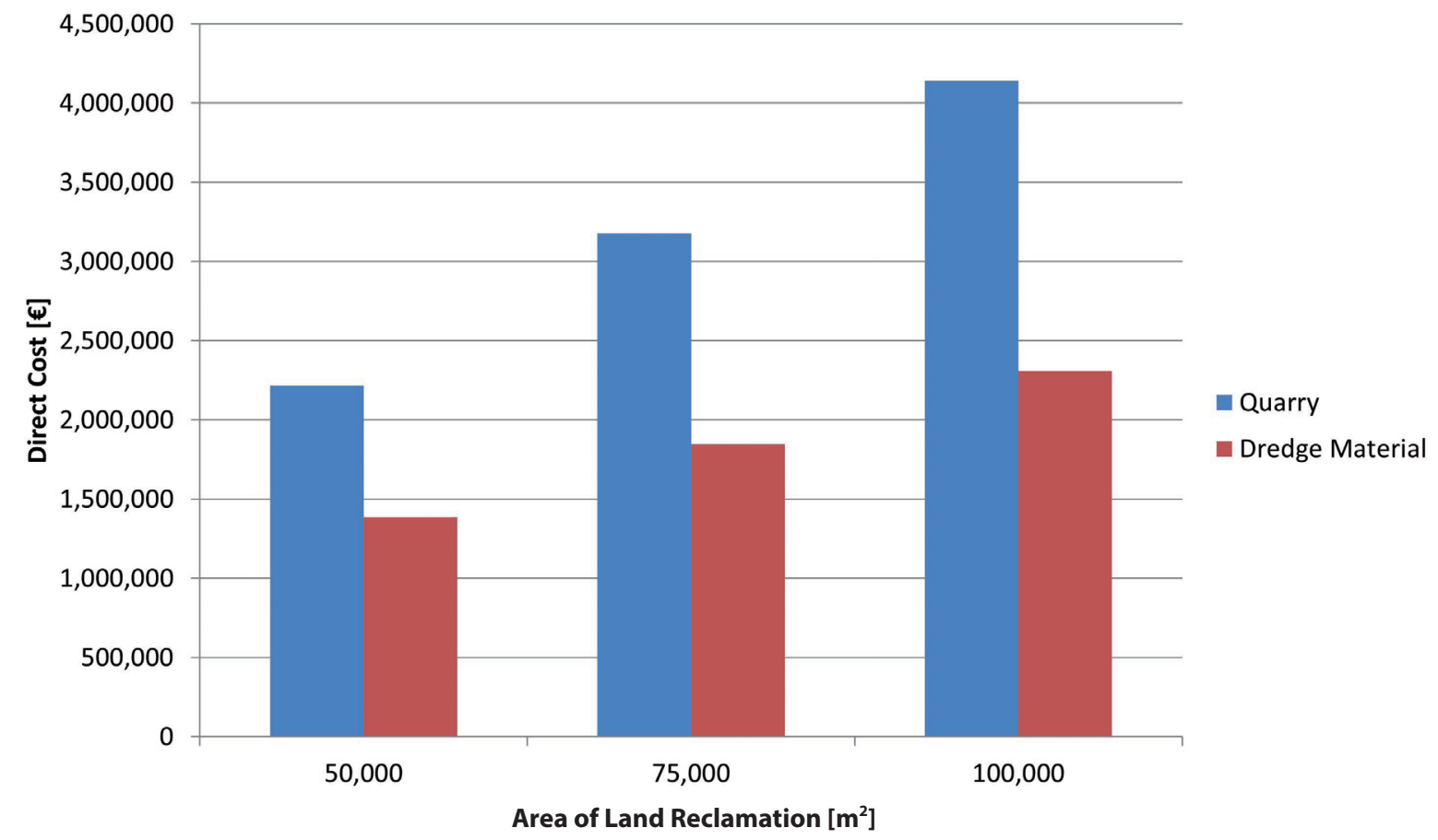

Fig. 8. Direct costs for Land Reclamation using quarry material or dredge sediment

Figure 8 presents the direct project cost results indicating that land reclamation using dredge sediment involves, for this scenario, a lower direct cost than sourcing quarry material, for the parameter value assumptions made. The analysis shows that the use of quarry material only becomes more direct cost competitive when the sail distance from the dredging site to the land reclamation site exceeds approximately $120 \mathrm{~km}$, a distance which is unsustainable and impractical. This indicates the potential, where appropriate and applicable, for dredge sediment to be used as a substitute for quarry based material. This is interesting and potentially valuable in the context of the potential reuse of non-primary sourced material contributing to the developing area of the circular economy. Contributions to GDP and jobs created during construction are greater for a quarry based source and related to the higher direct project costs.

\section{DISCUSSION}

An economic analysis for land reclamation using dredged sediment has been presented. This sediment management approach has also been compared to a number of other approaches (wetland creation and offshore disposal) for the same project scenario; a sediment volume of $100,000 \mathrm{~m}^{3}$ yielding a 50,000 $\mathrm{m}^{2}$ area of reclaimed land (or area of wetland created) with an average $2 \mathrm{~m}$ fill depth and a $10 \mathrm{~km}$ sail distance for offshore disposal. Figure 9 presents results for the direct cost analysis and Figures 10 and 11 present results for the economic impacts.

These results show, for the modelling assumptions made, that disposal at sea yields the lowest direct project cost and that wetland creation and land reclamation have higher but relatively similar direct project costs. It should be noted that additional direct costs for disposal at sea, for which a monetary value is not allocated in the economic model, may include habitat loss and reduced fish populations involving potential monetary loss. The sediment management scenarios which involve higher project direct costs also generate greater economic impacts.

The lowest direct costs are found for disposal at sea which reflects sediment management practice in Ireland where offshore disposal is most common for the fine grained fraction, for typical sail distances up to approximately $40 \mathrm{~km}$. This practice is driven primarily by the direct project cost factor but also by the lack of available knowledge and guidance on other potentially feasible sediment management approaches. 


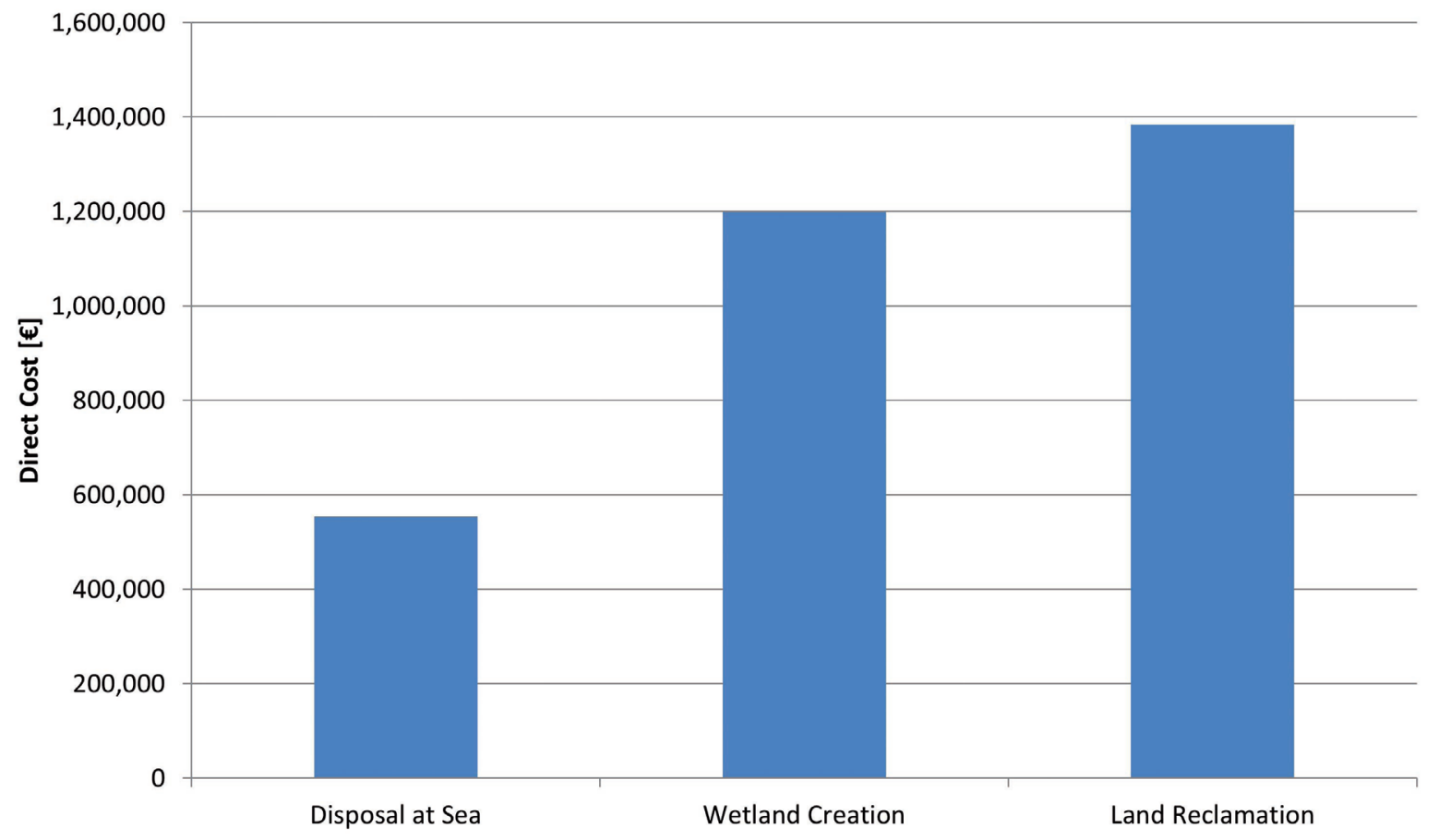

Fig. 9. Direct costs for a Range of Sediment Management Approaches

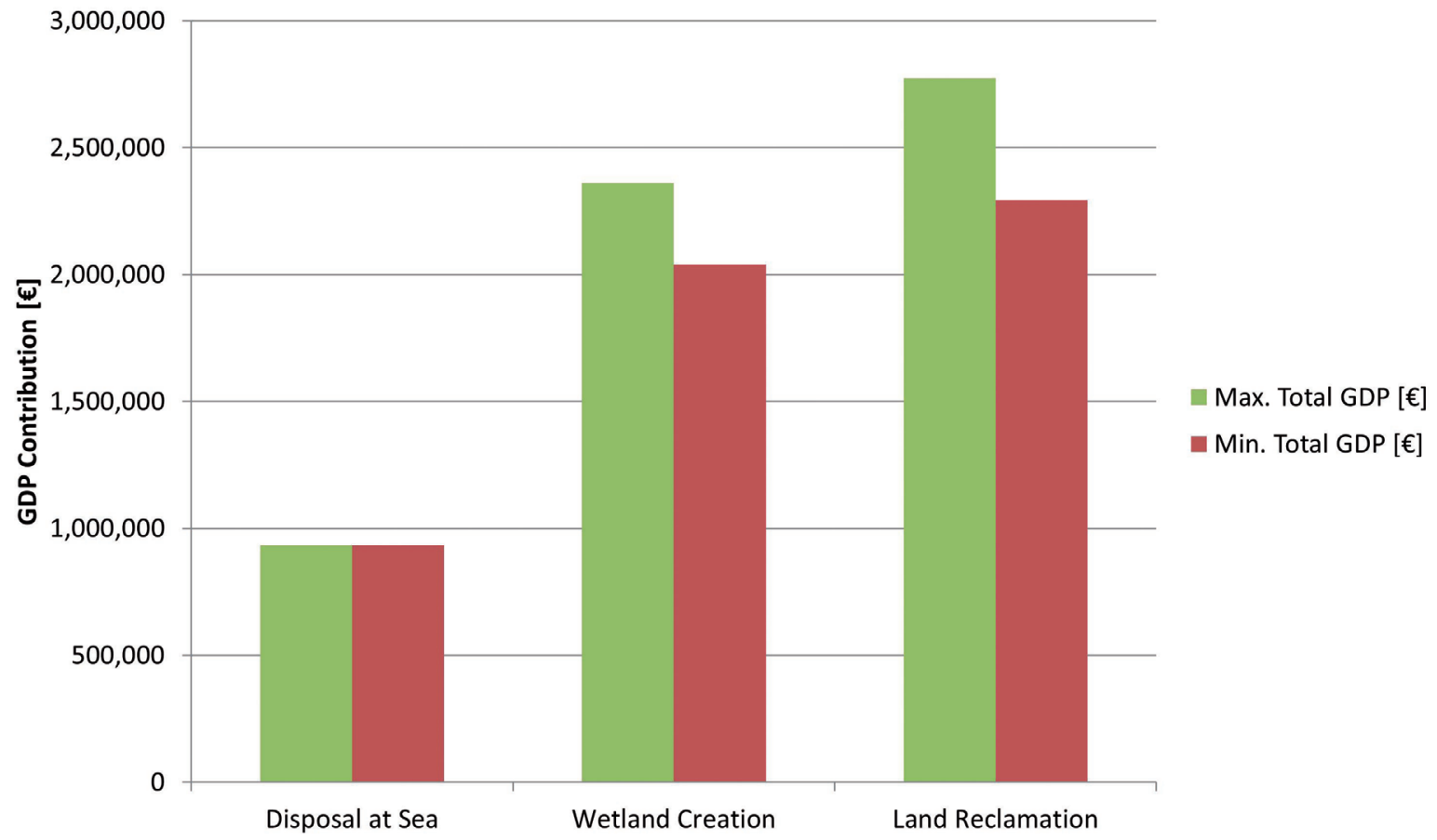

Fig. 10. Contribution to GDP for a Range of Sediment Management Approaches 


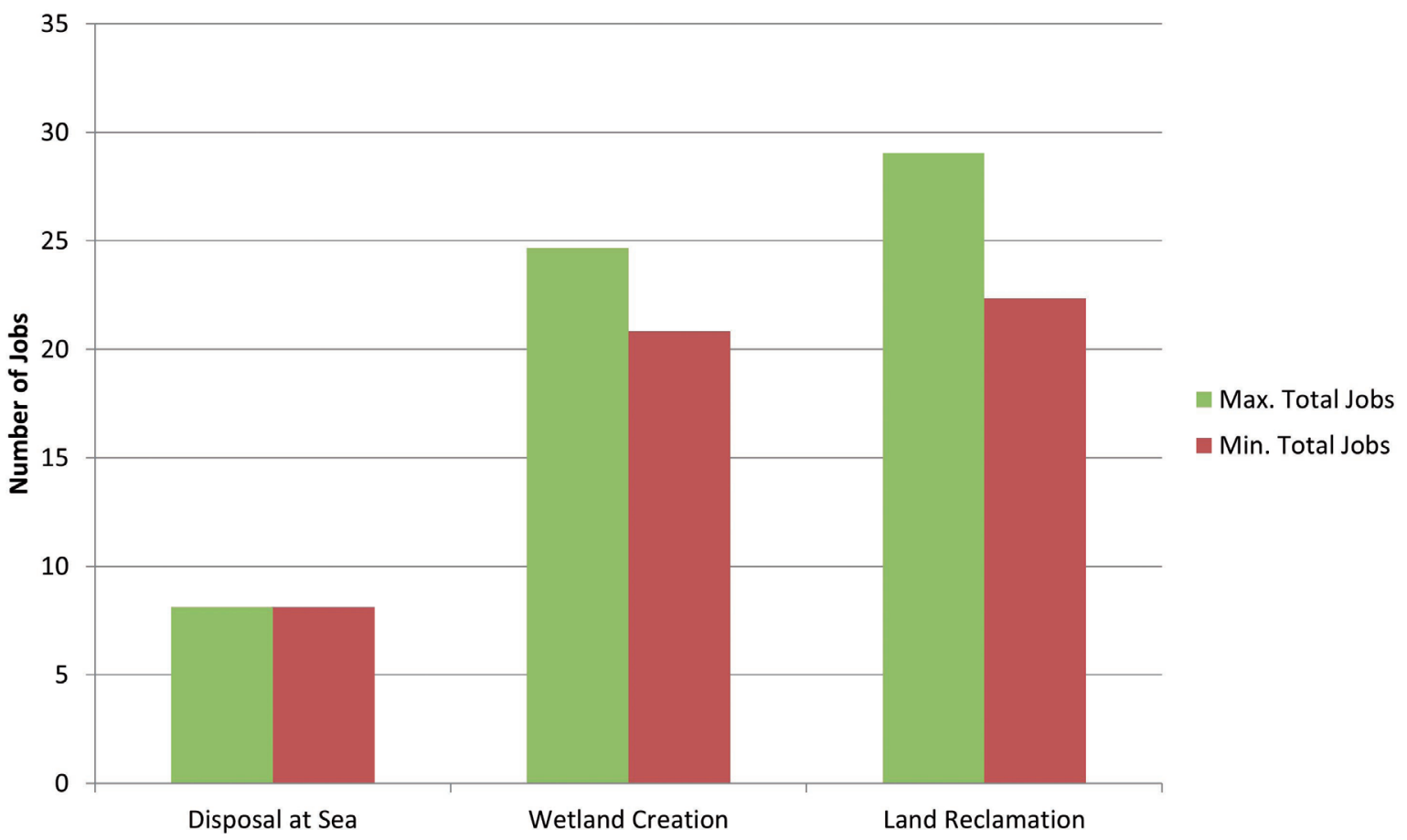

Fig. 11. Contribution to Employment for a Range of Sediment Management Approaches

Wetland creation/enhancement clearly has potential for greater application for Ireland and the modelling results show that direct project costs are likely to be higher than for a disposal at sea project (unless the sail distances are excessive at above approximately $300 \mathrm{~km}$ ). Higher direct costs lead to greater economic impacts (GDP and employment), which are limited to the lifespan of the project. However there are also potential long term benefits including the potential value of the wetland area created.

A range of additional benefits may be derived from wetland ecosystems, known as ecosystem services. Such benefits may include environmental amenity/natural environment, flood and flow control, coastal protection, storm buffering, sediment retention, water quality maintenance/nutrient retention due to the filtering mechanism, recreational amenity and biological diversity. Wetland ecosystem services include the categories of supporting services (e.g., flood regulation), regulating services (e.g. purification of water) and cultural services (e.g., recreational amenity). The treatment of wetland valuation has received significant attention in recent years and is presented by, for example, Brander et al. (2006) and specifically for coastal wetlands in an Irish context by Norton et al. (2016) where attempts are underway to place an offset value on coastal wetland systems, for example by costing engineered sea wall systems which provides a similar coastal flood protection function. A broader review of ecosystem services and economics is presented by, for example, Gomez-Baggethun et al. (2010). Monetary valuation of such ecosystem services is not included in the current economic model but such services do provide significant potential benefits, particularly for larger scale projects. Wetland creation or enhancement may thus be an appropriate and sustainable solution depending on the project specifics and consideration of a wide range of parameters, including ecosystem services.

Road sub-base material using dredged sediment, a product based approach, has also been modelled for a $50 \mathrm{~km}$ long road, $8 \mathrm{~m}$ wide with an average sub-base thickness of $0.25 \mathrm{~m}$. Sediment dewatering and material processing costs are set in the model at $€ 13 / \mathrm{m}^{3}$ and $€ 100 / \mathrm{m}^{3}$ respectively. The direct project cost is estimated in excess of $€ 13$ million with significantly larger contributions to GDP 
and employment (approximately 280 jobs are estimated to be created during the project duration). The equivalent project using quarry based aggregate involves an estimated direct cost of $€ 5$ million (for an average trucking distance of $25 \mathrm{~km}$ ). It may be concluded that this is not a viable sediment management option unless the processing and road construction site are adjacent to the dredge site; viability seems limited to an 'opportunity' on a site-specific basis otherwise it is generally prohibitively expensive. Potential benefits of this approach include replacement of a primary finite aggregate material source with a secondary source with inherent benefits to the circular economy and the general contribution to regional infrastructural development.

\section{CONCLUSIONS}

An economic model has been developed which analyses direct cost and economic impacts of different sediment management projects.

A detailed economic analysis for land reclamation is undertaken indicating the primary project elements contributing to the direct project cost and the potential impact on the wider economy. The analysis indicates that the direct project cost of land reclamation using dredged sediment will generally exceed that of disposal at sea, for the typical sail distances experienced in Ireland (less than 40 $\mathrm{km}$ for the project scenario analysed) and thus the creation of land as an opportunity from a dredging project is likely to have a higher direct project cost and greater economic impact and in the longer term the land created may yield a greater economic value than indicated by the economic model.

Analysis of land reclamation using dredged sediment or quarry based material indicates the potential that exists for dredged sediment to be used as a substitute for primary sourced material, for suitable site conditions. This shows the potential for the application of secondary materials in the context of the concept of the circular economy, particularly for larger scale projects with potential direct cost and primary material savings, in addition to potential $\mathrm{CO}_{2}$ savings through reduced material transport requirements.

Comparison of a range of sediment management approaches for a specific defined project is presented with disposal at sea providing the lowest direct project cost for typical sail distances in Ireland; wetland creation and land reclamation however provide a range of other economic, environmental and infrastructural benefits. These greater benefits are also likely to be enhanced by longer-term returns from land reclamation and wetland creation that are not modelled as part of this analysis. The analysis presented in this paper provides strong potential for a larger research agenda to evaluate longer term economic impacts of alternative sediment management approaches, which will enable robust evaluation of the relative benefits of each use.

The model provides significant insight into the economic aspect of sediment management projects and has the potential to facilitate stakeholders across the sector, although model results must be considered in the context of the broader environmental and societal impacts and the needs and requirements of the stakeholder community.

The authors wish to acknowledge the funding received for the CEAMaS Project through the INTERREG IVB programme and the European Regional Development Fund (ERDF).

The authors would like to thank the Irish Central Statistics Office, the United Kingdom Office for National Statistics and the Scottish Government's National Statistics Office who provided economic data. The authors also wish to thank the other CEAMaS project partners (Belgian Building Research Institute (BBRI), Belgium; Delft University of Technology (TU Delft), The Netherlands; Ecole Centrale de Lille (ECLille), France; The French Geological Survey (BRGM), and Université Lille 1, France) for the provision of data and advice.

\section{REFERENCES}

Blanco I. \& Kjaer C., 2009. Wind at work. Wind energy and job creation in the EU. European Wind Energy Association.

Bortone G. \& Palumbo L., 2007. Sustainable management of sediment resources. Volume 2: Sediment and Dredged Material Management. Elsevier, The Netherlands.

Brander L., Florax R. \& Vermaat J., 2006. The empirics of wetland valuation: a comprehensive summary and a meta-analysis of the literature. Environmental \& Resources Economics, 33, 223-250. 
CEAMaS, 2015. Civil engineering applications for marine sediments. [on-line:] http://www.ceamas.eu [access: 21.10.2015].

Central Dredging Association, 2015. Integrating adaptive environmental management into dredging projects. Radex Innovation Centre, Rotterdamseweg HD Delft, The Netherlands.

Central Statistics Office, 2014, Irish wage data. Dublin, Ireland.

D’Alisa G., Demaria F. \& Kallis G. (eds.), 2015. Degrowth: A vocabulary for a new era. Routeledge, New York.

DredgDikes Project, 2013. Dredge material in dike construction. [on-line:] http://www.dredgdikes.eu/ [access: 21.10.2015].

DTZ Sherry Fitzgerald, 2014. Irish land market-summer review 2014. Dublin, Ireland.

Eisma D., 2006. Dredging in Coastal Waters. Taylor \& Francis, United Kingdom.

Environment Agency, WRAP, 2010. Technical report on the beneficial use of marine sediment from capital and maintenance dredging in land based projects. Oxfordshire, UK.

Gomez-Baggethun E., de Groot R., Lomas P. \& Montes C., 2010. The history of ecosystem services in economic theory and practice: from early notions to markets and payment schemes. Ecological Economics, 69, 1209-1218.

Harrington J. \& Smith G., 2013. Guidance on the beneficial use of dredge material in Ireland. Irish Environmental Protection Agency.

Harrington J., Sutton S. \& Lewis A., 2004. Dredging and dredge disposal and reuse in Ireland - a small island perspective. [in:] Dredging in a Sensitive Environment. Proceedings of the World Dredging Congress XVII, Hamburg, Germany, 27 September-1 October 2004, B4-5, World Organization of Dredging Associations (WODA), 1-14.

Hawdon D. \& Pearson P., 1995. Input-output simulations of energy, environment, economy interactions in the UK. Energy Economics, 17, 1, 73-86.

Herman S., Pieters A., Glaser D., Gregoire P., Priez C., Desmoulin D. \& Guglielmetti D., 2014. A lustrum of valorisation of contaminated sediments from the Port of Dunkirk (France). [in:] Proceedings of the South Baltic Conference on Dredged Materials in Dike Construction Rostock, 10-12 April 2014, 137-144.

Irish Dumping At Sea (Fees) Regulations, 2012. S.I. No. 270 of 2012.

Irish Waste Management (Landfill Levy) (Amendment) Regulations, 2013. S.I. No. 194 of 2013.

Ivanova G. \& Rolfe J., 2011. Using input-output analysis to estimate the impact of a coal industry expansion on regional and local economies, impact assessment and project appraisal, 2011. Beech Tree Publishing, 29, 4, 277-288.

Kammen D.M., Wei M. \& Patadia S., 2010. Putting renewables and energy efficiency to work: how many jobs can the clean energy industry generate in the US? Energy Policy, 38, 2, 919-931.

Leontief W., 1951. Input output economics. Scientific American, 185, 15-21.
Norton D., Hynes S. \& Boyd J., 2016. Valuing Ireland's ecosystem services (VIBES). Irish Environmental Researchers' Colloquium, University of Limerick, Ireland.

OSPAR Commission, 2009. Assessment of the environmental impact of dredging for navigational purposes. United Kingdom.

PIANC, 1992. Beneficial use of dredged material. EnviCom Working Group 19, Brussels, Belgium.

PIANC, 2009a. Long term management of confined disposal facilities for dredged material. EnviCom Working Group 11, Brussels, Belgium.

PIANC, 2009b. Best management practices applied to dredging and dredged material disposal projects for protection of the environment. EnviCom Working Group 13, Brussels, Belgium.

PIANC, 2009c. Dredged material as a resource-options and constraints. EnviCom Working Group 14, Brussels, Belgium.

PIANC, 2013. Water injection dredging. MarCom Working Group 51, Brussels, Belgium.

PRISMA, 2014. Promoting integrated sediment management - Final Report. [on-line:] http://www.prisma-projects. eu/images/Final\%20report\%20PRISMA.pdf [access: 22.10.2015].

Sheehan C., 2012. An analysis of dredge material reuse techniques for Ireland. Cork Institute of Technology, Ireland [Ph.D. thesis].

Sheehan C. \& Harrington J., 2012. Management of dredge material in Ireland - a review. Waste Management, 32, 1031-1044.

SMOCS, 2012. Sustainable management of contaminated sediment. Baltic Sea Region Programme Project, [on-line:] http://smocs.eu/ [access: 22.10.2015].

TIDE, 2013. Tidal river development project 2013. [on-line:] http://http://www.tide-project.eu/ [access: 22.10.2015].

United States Army Corps Engineers, 1987. Beneficial uses of dredged material. EM 1110-2-5026, US Army Corps of Engineers, Washington, DC.

United States Army Corps Engineers \& United States Environmental Protection Agency, 2007. Identifying, planning, and financing beneficial use projects using dredged material: Beneficial Use Planning Manual. EPA842-B-07-001. U.S. Environmental Protection Agency \& U.S. Army Corps of Engineers, Washington, DC.

United States Army Corps Engineers, 2012. Dredging operations and environmental research. [on-line:] http://el. erdc.usace.army.mil/dots/doer/doer.html [access: 22.10 . 2015].

United States Army Corps Engineers, 2014. Economical treatment of dredged material to facilitate beneficial use. ERDC/ EL TR-14-11. Environmental Laboratory, U.S. Army Engineer Research and Development Center, Vicksburg, USA.

USAR, 2016. Using sediments as a resource. [on-line:] http:// wrt.org.uk/project/usar/ [access: 22.10.2015].

Wiedmann T., 2009. A review of recent multi-region inputoutput models used for consumption-based emission and resource accounting. Ecological Economics, 69, 2, 211-222. 